\title{
B complex vitamins for analgesic therapy
}

\author{
O uso de vitaminas do complexo $B$ em terapêutica analgésica
}

Fernanda Martins Gazoni', William Rafael Malezan², Fânia Cristina Santos ${ }^{1}$

DOI 10.5935/1806-0013.20160013

\section{ABSTRACT}

BACKGROUND AND OBJECTIVES: The B complex vitamins have been used as single therapy or combined to other drugs, such as anti-inflammatory drugs, in different clinical situations, such as degenerative spinal diseases, rheumatologic diseases, polyneuropathies and in different postoperative situations. This study aimed at identifying in the scientific literature most recent evidences of the use of $\mathrm{B}$ complex vitamins as analgesic therapy and at describing clinical situations where their analgesic action could be observed.

CONTENTS: A search was carried out in Pubmed, Medline, LILACS, Cochrane Library and Scielo databases, contemplating the last 10 years and titles in Portuguese, Spanish and English. Keywords were: "pain", "B complex vitamins", "management", "vitamin B1", "vitamin B6", "vitamin B12", "thiamine”, "pyridoxine" and "cyanocobalamin". Among 40 studies found, we have selected just musculoskeletal and neuropathic pain trials with humans, and where B complex vitamins were used as analgesic agents. From these, 13 studies were selected for meeting inclusion criteria. In all of them, B complex vitamins played roles in analgesia, even when in single therapy. B complex vitamins had also anti-inflammatory and anti-pruritus action, in addition to improving functionality.

CONCLUSION: Existing studies, although scarce and heterogeneous, have shown that B complex vitamins have analgesic effect. They are considered safe and have low cost and have shown to be a good option as adjuvant analgesic therapy.

Keywords: B complex vitamins, Management, Pain.

1. Universidade Federal de São Paulo, Serviço de Doenças Osteoarticulares e Dor, Disciplina de Geriatria e Gerontologia, São Paulo, SP, Brasil.

2. Hospital Israelita Albert Einstein. São Paulo, SP, Brasil.

Submitted in September 06, 2015.

Accepted for publication in January 18, 2016.

Conflict of interests: none - Sponsoring sources: none.

Correspondence to:

Fernanda Martins Gazoni

Rua Francisco de Castro, 105 - Vila Clementino

04020-050 São Paulo, SP, Brasil.

E-mail: fmgazoni@gmail.com

(C) Sociedade Brasileira para o Estudo da Dor

\section{RESUMO}

JUSTIFICATIVA E OBJETIVOS: As vitaminas do complexo B têm sido utilizadas em monoterapia ou combinada a outros fármacos, como os anti-inflamatórios, em diversas situaçôes clinicas, como por exemplo, nas doenças degenerativas da coluna, doenças reumatológicas, polineuropatias e nos pós-operatórios diversos. O objetivo deste estudo foi identificar na literatura científica as evidências mais recentes do uso de vitaminas do complexo $\mathrm{B}$ como terapia analgésica e descrever as situaçôes clínicas em que se pode verificar a sua ação analgésica.

CONTEÚDO: Realizada a revisão bibliográfica na base de dados do Pubmed, Medline, LILACS, Biblioteca Cochrane e Scielo, contemplando os últimos 10 anos, títulos em português, espanhol e inglês. Os descritores utilizados foram: "Dor", "vitaminas do complexo B", "tratamento", "vitamina B1", "vitamina B6”, “vitamina B12", "tiamina", "piridoxina" e "cianocobalamina”. Dentre os 40 estudos encontrados selecionaram-se apenas os trials em dor musculoesquelética e neuropática com seres humanos, e em que as vitaminas do complexo B configuraram-se como agentes analgésicos. Foram selecionados então 13 estudos que satisfizeram esses critérios de inclusão. Em todos eles as vitaminas do complexo B desempenharam papéis na analgesia, inclusive quando em monoterapia. As vitaminas do complexo $\mathrm{B}$ também apresentaram ação anti-inflamatória, anti-pruriginosa, na funcionalidade e na qualidade de vida. CONCLUSÃO: Os estudos existentes, apesar de heterogêneos, demonstraram que as vitaminas do complexo B possuem efeito analgésico em síndromes dolorosas neuropática e nociceptiva, e que por serem esses fármacos seguros e de baixos custos poderiam representar boas opçôes na terapêutica analgésica no nosso meio. Descritores: Dor, Tratamento, Vitaminas do complexo B.

\section{INTRODUCTION}

B complex vitamins (Bvits) belong to the hydrosoluble group of vitamins, being made up of thiamine, riboflavin, niacin, niacinamide, pyridoxine, cobalamin, folic acid, pantothenic acid, biotin, choline, inositol and para-aminobenzoic acid (PABA). Among their major representatives to manage pain there are vitamins $\mathrm{B} 1$ (thiamine), B6 (pyridoxine) and B12 (cyanocobalamin) ${ }^{1}$.

Bvits are important for nucleic acid and proteins synthesis, as well as for phosphatidylcholine synthesis. Phosphatidylcholine is a cell membrane phospholipid which is transformed in choline which shall be used for acetylcholine synthesis which is a major neurotransmitter ${ }^{2-4}$. Possible Bvits analgesic and anti-neuralgic mechanisms (especially vitamins B1 and B12) shown in experimental animal studies include: interaction with mediators caus- 
ing pain in nociceptors, increasing availability and effectiveness of norepinephrine and 5-hydroxitriptamine in pain inhibitory descending pathway; regeneration of damaged nerve fibers; stabilization of electric nervous excitability inhibiting ectopic discharges; and improved axonal transport, increasing nervous conduction velocity ${ }^{5-7}$.

For many years, Bvits have been used in monotherapy or combined with other drugs, such as anti-inflammatory drugs, in several clinical situations, such as degenerative spinal diseases, rheumatologic diseases, polyneuropathies (especially diabetic neuropathy) and in different postoperative periods $s^{1-4}$. Notwithstanding several animal studies showing positive evidences of Bvits both for inflammatory and neuropathic pain, few human clinical trials have shown the same effects, which made Bvits analgesic efficacy controversial ${ }^{3,8}$.

Cochrane Library has published in 2008 a review with 13 peripheral alcoholic and diabetic neuropathy trials, in a total of 741 participants, with emphasis to just one study with benfotiamine (derivative of vitamin B1). This study has observed a possible benefit of benfotiamine with slight increment on vibratory perception as compared to placebo. The review has stressed that high doses of Bvits are more effective than low doses, but the use of other therapies as compared to vitamins is more effective in the short term. So, it was suggested that further studies should be carried out to confirm the possible effect of Bvits on peripheral neuropathies?.

After Cochrane's publication, some studies were carried out to evaluate analgesic effects of Bvits in the management of nociceptive and neuropathic pain. So, due to more recent publica- tions and still with questions about the real role of Bvits in the clinical practice involving different pain situations, this review is intended to update information on the use of such vitamins to manage pain.

This study aimed at identifying in the scientific literature most recent evidences of the use of Bvits as analgesic therapy and at describing clinical situations in which their analgesic action could be observed, both in monotherapy and in adjuvant therapy.

\section{CONTENTS}

This is a study carried out by means of integrative literature review, following the stages recommended for studies of this nature. Literature review was carried out in Pubmed, LILACS and Scielo databases, looking for scientific articles published in the last 10 years, from 2005 to 2015, in English, Portuguese and Spanish. Descriptors were "pain", "B complex vitamins", "management", "vitamin B1", "vitamin B6", "vitamin B12", "thiamine", "pyridoxine" and "cyanocobalamin". It should be stressed that these same descriptors were identified in DEcS (Health Science Descriptors).

Narrative reviews and systematic reviews, experience reports, case reports and clinical trials were included in this scientific search. Among 40 studies found, we have selected just musculoskeletal and neuropathic pain trials with human beings, in which Bvits were used as analgesic agents.

We have selected 13 trials which have met herein established inclusion criteria. Table 1 is a summary of selected trials and their primary results.

Table 1. Clinical trials with vitamin B in musculoskeletal and neuropathic pain

\begin{tabular}{|c|c|c|c|c|}
\hline Authors & Type of trial & Sample & Objectives/Methods & Results/Conclusion \\
\hline $\begin{array}{l}\text { Ponce- } \\
\text { Monter et al. }{ }^{1}\end{array}$ & $\begin{array}{l}\text { Randomized, } \\
\text { controlled, } \\
\text { Double-blind } \\
\text { study }\end{array}$ & $\begin{array}{l}122 \text { patients aged } \\
\text { between } 18 \text { and } \\
55 \text { yeras, with acu- } \\
\text { te pain associated } \\
\text { to lower limb frac- } \\
\text { ture, VAS } \geq 50 \mathrm{~mm}\end{array}$ & $\begin{array}{l}\text { To compare the efficacy of diclofenac } \\
\text { ( } 75 \mathrm{mg} \text { ) associated to thiamine }(100 \mathrm{mg}) \text {, } \\
\text { pyridoxine (100mg) and cyanocobala- } \\
\text { min (1mg), to diclofenac alone (same } \\
\text { dose). Muscular injection } 2 \mathrm{x} / \text { day, } 24 \mathrm{~h} \\
\text { before surgery and } 24 \mathrm{~h} \text { after }\end{array}$ & $\begin{array}{l}\text { Decreased pain in the first } 4 \mathrm{~h} \text { (VAS }>30 \mathrm{~mm}) \\
\text { in both groups. With association of vitamin B } \\
\text { there has been further effectiveness as from } \\
8 \mathrm{~h} \text { of the first application, being superiority } \\
\text { maintained for } 48 \mathrm{~h}(\mathrm{p}<0.05) \text {. Conclusion was } \\
\text { that the association of vitamin B to diclofe- } \\
\text { nac has increased its analgesic efficacy. }\end{array}$ \\
\hline Mibielli et al. ${ }^{7}$ & $\begin{array}{l}\text { Randomized, } \\
\text { controlled, } \\
\text { Double-blind } \\
\text { study }\end{array}$ & $\begin{array}{l}372 \text { patients, } \\
\text { mean age of } 66 \\
\text { years, with acute } \\
\text { low back pain }\end{array}$ & $\begin{array}{l}\text { To evaluate vitamins } B 1,6 \text { and } 12 \text { for } \\
\text { pain. Randomization to diclofenac }(50 \mathrm{mg}) \\
\text { + pyridoxine }(50 \mathrm{mg})+\text { thiamine }(50 \mathrm{mg})+ \\
\text { cyanocobalamin }(1 \mathrm{mg})(\mathrm{GDB}) \text {, and diclo- } \\
\text { fenac alone }(50 \mathrm{mg})(\mathrm{GD}) \text {, by oral route } 2 \mathrm{x} / \\
\text { day, for no longer than } 7 \text { days. }\end{array}$ & $\begin{array}{l}\text { GDB has more effectively improved pain af- } \\
\text { ter } 3 \text { days, (decrease of } \geq 20 \mathrm{~mm} \text { in VAS), and } \\
\text { there has been personal satisfaction in this } \\
\text { group. GDB was also better for functionality } \\
\text { and mobility }(p<0.05)\end{array}$ \\
\hline $\begin{array}{l}\text { Maladkar, } \\
\text { Tekchandani, } \\
\text { Dave }^{10}\end{array}$ & $\begin{array}{l}\text { Open, explora- } \\
\text { tory, prospecti- } \\
\text { ve, multicenter } \\
\text { study }\end{array}$ & $\begin{array}{l}497 \text { patients aged } \\
\text { between } 40 \text { and } \\
75 \text { years, with pe- } \\
\text { riphearl neuopathy } \\
\text { of different origins }\end{array}$ & $\begin{array}{l}\text { To evaluate the efficacy and safety of } \\
\text { the associations of methylcobalamin } \\
(1500 \mu \mathrm{g}) \text {, alpha-lipolic acid }(200 \mathrm{mg}) \text {, } \\
\text { folic acid }(5 \mathrm{mg}) \text {, biotin }(5 \mathrm{mg}) \text {, benfotia- } \\
\text { mine }(50 \mathrm{mg}) \text { and vitamin } \mathrm{B} 6(5 \mathrm{mg}), 1 \mathrm{x} / \\
\text { day, O, for } 12 \text { weeks. }\end{array}$ & $\begin{array}{l}\text { Major improvement of neuropathic symp- } \\
\text { toms already in the } 4^{\text {th }} \text { week. With } 12 \text { weeks } \\
\text { there has been improvement in all symptoms } \\
(p<0.05): 78 \% \text { pain decrease, } 92.1 \% \text { in num- } \\
\text { bness, } 96.9 \% \text { in muscle weakness, } 96 \% \text { in } \\
\text { tingling and } 99.2 \% \text { in burning. The efficacy } \\
\text { and safety of vitamin B associations for peri- } \\
\text { pheral neuropathies was confirmed. }\end{array}$ \\
\hline $\begin{array}{l}\text { Negrão et } \\
\text { al. }{ }^{11}\end{array}$ & $\begin{array}{l}\text { Open, explora- } \\
\text { tory, prospecti- } \\
\text { ve, multicenter } \\
\text { study }\end{array}$ & $\begin{array}{l}212 \text { patients aged } \\
\text { between } 19 \text { and } \\
92 \text { years, with } \\
\text { neuropathic pain } \\
\text { of different origins }\end{array}$ & $\begin{array}{l}\text { To evaluate the efficacy of vitamin B12 } \\
(3 \mu \mathrm{g}) \text { associated to uridine monophos- } \\
\text { phate ( } 50 \mathrm{mg}) \text { and folic acid }(400 \mu \mathrm{g}) \\
\text { simultaneously with regular use of } \\
\text { analgesics (paracetamol, tramadol and } \\
\text { anti-inflammatory drugs), O } 1 \mathrm{x} / \text { day, forr } \\
60 \text { days. }\end{array}$ & $\begin{array}{l}\text { Significant pain improvement according to } \\
\text { Pain Detect (from } 17.5 \text { to } 8.8 \text { points), and of } \\
\text { analgesic consumption in } 75.6 \% \text { of patients. } \\
\text { The conclusion was that the association of } \\
\text { vitamin B12, uridine and folic acid was effec- } \\
\text { tive for pain and also has allowed lower anal- } \\
\text { gesic consumption. }\end{array}$ \\
\hline
\end{tabular}


Table 1. Clinical trials with vitamin B in musculoskeletal and neuropathic pain - continuation

\begin{tabular}{|c|c|c|c|c|}
\hline Authors & Type of trial & Sample & Objectives/Methods & Results/Conclusion \\
\hline Talaei et al. ${ }^{12}$ & $\begin{array}{l}\text { Randomized } \\
\text { blind study }\end{array}$ & $\begin{array}{l}100 \text { patients be- } \\
\text { tween } 18 \text { and } 53 \\
\text { years of age, with } \\
\text { diabetic polyneu- } \\
\text { ropathy }\end{array}$ & $\begin{array}{l}\text { To compare the efficacy of vitamin B12 } \\
\text { and nortriptyline on neuropathic symp- } \\
\text { toms. Randomization for } 2 \text { groups: } \\
2000 \mu \mathrm{g} \text { vitamin B12, IM } 2 x / \text { week or } \\
\text { nortriptyline } 10 \mathrm{mg} \text { at night, for } 3 \text { mon- } \\
\text { ths. }\end{array}$ & $\begin{array}{l}\text { Better efficacy of vitamin B12 on pain, pares- } \\
\text { thesia and tingling, with statistical significan- } \\
\text { ce }(p<0.001) \text {. without statistical significance } \\
\text { in vibratory sensitivity, proprioception "pri- } \\
\text { cking" and nervous conduction }\end{array}$ \\
\hline $\begin{array}{l}\text { Stracke et } \\
\text { al. }{ }^{13}\end{array}$ & $\begin{array}{l}\text { Randomized, } \\
\text { controlled, } \\
\text { double-blind } \\
\text { study }\end{array}$ & $\begin{array}{l}165 \text { patients, aged } \\
\text { between } 42 \text { and } \\
73 \text { years, with dia- } \\
\text { betic neuropathy }\end{array}$ & $\begin{array}{l}\text { To evaluate the efficacy and safety of } \\
\text { benfotiamine }(\mathrm{Bf}) \text {. Randomization for } 3 \\
\text { groups: } \mathrm{Bf} 600 \mathrm{mg} / \text { day, } \mathrm{Bf} 300 \mathrm{mg} / \mathrm{day} \\
\text { and placebo for } 6 \text { weeks }\end{array}$ & $\begin{array}{l}\text { Slight improvement of neuropathic symp- } \\
\text { toms with } \mathrm{Bf} \text {, more pronounced with higher } \\
\mathrm{Bf} \text { dose. Conclusion was that } \mathrm{Bf} \text { was a the- } \\
\text { rapeutic option for diabetic polyneuropathy. }\end{array}$ \\
\hline Xu et al..$^{14}$ & $\begin{array}{l}\text { Randomized, } \\
\text { controlled, } \\
\text { blind study }\end{array}$ & $\begin{array}{l}98 \text { patients, age } \\
\geq 50 \text { years, with } \\
\text { sub-acute, mo- } \\
\text { derate to severe } \\
\text { post-herpetic neu- } \\
\text { ralgia, for at least } \\
120 \text { days. }\end{array}$ & $\begin{array}{l}\text { To evaluate the efficacy of oral or lo- } \\
\text { cal methylcobalamin for pain relief and } \\
\text { DLA improvement. Randomization for } \\
3 \text { groups: methylcobalamin } 1000 \mu \mathrm{g} \text { SC } \\
1 \times / \text { day, lidocaine } 1 \% \text { SC } 30 \mathrm{mg} 1 \times / \text { day } \\
\text { and methylcobalamin } 0.5 \mathrm{mg}, \mathrm{O} 3 \mathrm{x} / \text { day, } \\
\text { for } 4 \text { weeks. }\end{array}$ & $\begin{array}{l}\text { SC methylcobalamin has progressively de- } \\
\text { creased pain, with superiority of this route as } \\
\text { compared to oral route or to lidocaine in con- } \\
\text { tinuous paroximal pain or alodynia. The con- } \\
\text { clusion was that SC methylcobalamin was } \\
\text { potential choice for sub-acute post-herpetic } \\
\text { neuralgia. }\end{array}$ \\
\hline
\end{tabular}

Xu et al. ${ }^{15} \quad$ Randomized, 90 patients betwe- To evaluate the efficacy of TENS combicontrolled, en 55 and 92 ye- ned to cobalamin applied in the painful blind study ars, with post-her- area. Randomization for 3 groups: TENS petic neuralgia for + cobalamin, TENS + $1 \%$ lidocaine and at least 120 days TENS + colabamin $(1000 \mu \mathrm{g}$ cobalamin and pain NS of $>440 \mathrm{mg}$ lidocaine). SC application in the in dermatomes T6 largest painful area after each TENS sesto $\mathrm{T} 10$

Xu et al. ${ }^{16}$ Randomized, 80 patients, age To evaluate the efficacy of local cocontrolled, between 26 and balamin and thiamine on pain, itching blind study 89 years, with com herpes zoster and pruritus score $\geq$ 4 for at least 20 days.

\section{and DLA. Randomization for 4 groups:} thiamine $(100 \mathrm{mg})$, methylcobalamin $(1000 \mu \mathrm{g}), 1 \%$ lidocaine $(30 \mathrm{mg})$ and thiamine associated to cobalamin

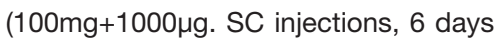
a week, for 4 weeks.

Chiu et al. ${ }^{17}$

Tandomized, 60 patients aged controlled, between 30 and double-blind 65 years, with study non-specific chronic low back pain

Mibielli et al. ${ }^{18}$ Randomized, 81 patients, age controlled, between 18 and double-blind 65 years, with study

non-traumatic acute pain in lumbar, cervical or hip region

Garg, Syngle, Randomized, 30 patients betweVohra $^{19}$ controlled, en 43 and 72 years double-blind of age, with knee study $\mathrm{OA}$

To evaluate the efficacy and safety of methylcobalamin on pain and incapacity according to Oswestry index. Randomization for methylcobalamin $500 \mu \mathrm{g}$ and placebo, by muscular route, $3 \mathrm{x}$ a week, for 2 months

To compare the efficacy and safety of the association of diclofenac (70mg)/ cholestyramine, nucleotides (uridine $1.5 \mathrm{mg}$ and cytidine $2.5 \mathrm{mg}$ ) and hydroxycobalamin $(1 \mathrm{mg})$ with the association of nucleotides (uridine $1.5 \mathrm{mg}$ and cytidine $2,5 \mathrm{mg}$ ) and hydroxycobalamin (1mg), $\mathrm{O}, 2 \mathrm{x} /$ day, for 10 days.

To evaluate efficacy and tolerability of the association benfotiamine $(50 \mathrm{mg})$, pyridoxamine $(50 \mathrm{mg})$ and methylcobalamin $(500 \mu \mathrm{g})$ as compared to placebo, $\mathrm{O}, 3 \mathrm{x} /$ day, for 24 weeks

Magaña-Villa et al. ${ }^{20}$
Randomized, 48 patients, be- To evaluate efficacy and safety of diclocontrolled, tween 59 and 68 fenac associated to vitamins B1, 6 and double-blind years of age, with 12 (diclofenac $75 \mathrm{mg}$, thiamine $100 \mathrm{mg}$, study severe knee AO pyridoxine $100 \mathrm{mg}$ and cyanocobalamin (pain NS $>7$ ) in the $5 \mathrm{mg}$ ) compared to diclofenac $(75 \mathrm{mg}$ ) preoperative pe- alone. Single muscular application $48 \mathrm{~h}$ riod of arthroplasty before surgery and pain evaluation for

$12 \mathrm{~h}$ sion, 6 days a week for 8 weeks.

TENS + cobalamin or TENS + cobalamin + lidocaine have significantly improved pain (decrease $\geq 30 \%)(p<0.05)$. TENS + lidocaine have not significantly improved pain. There have been significant DLA increments with TENS + cobalamin and TENS + cobalamin + lidocaine, without statistically significant differences among them.

There has been significant improvement in itching with thiamine, of pain with cobalamin and of both with the association of cobalamin and thiamine, in addition to improved DLA with cobalamin and cobalamin associated to thiamine. The conclusion was that thiamine had major anti-itching action, cobalamin analgesic action and the association of both had dual actions without synergy.

Methylcobalamin has significantly improved pain and incapacity as compared to placebo. Conclusion was that methylcobalamin was effective and safe for non-specific chronic low back pain.

Pain improvement (decrease $>30 \mathrm{~mm}$ in VAS) in approximately $87.5 \%$ of the diclofenac group (GD) and in $51.23 \%$ of the nondiclofenc group (GND), p>0.0006, improved functionality in $80 \%$ of GD and $29.3 \%$ of GND, $p<0.0001$. Conclusion was that GD was superior, but there has also been significant analgesia for GND

Statistically significant improvement of pain and clinical indices of disease activity, as well as decrease of one biomarker of disease activity (CRP) with vitamins. Conclusion was that the association of vitamins B1, 6 and 12 has improved funcionality on DLA and joint mobility

Analgesic superiority of the association of vitamins B1, 6 and 12 to diclofenac. There has also been increased analgesic duration for diclofenac in the preoperative period of arthroplasty $(p<0.05)$ 


\section{DISCUSSÃO}

This study has reviewed recent publications and also published after a major Cochrane's systematic review from 2008 about the role of Bvits to manage peripheral neuropathies, time when available information were insufficient to determine the real clinical benefit of those vitamins as analgesics. We have found different results with more recent studies. It was observed that Bvits had significant analgesic effects in polyneuropathies, low back pain, osteoarthritis (OA) and post-herpetic neuralgias, both as adjuvant drugs and as monotherapy. In addition, Bvits had anti-inflammatory and anti-itching action, the latter in post-herpetic neuralgia patients and have also improved functionality. When those vitamins were associated to conventional acute or chronic pain management, they have decreased time for analgesic and antiinflammatory drugs consumption, thus contributing to less deleterious adverse effects in some individuals ${ }^{1,7,10-20}$.

The review of publications on Bvits for neuropathic pain, a total of 6 studies, point to beneficial effects, but with different doses and administration routes. Maladkar, Tekchandani and Dave ${ }^{10}$, studying peripheral neuropathic pain patients, have shown that after 12 weeks of Bvits administration (1500 $\mathrm{mg}$ methylcobalamin, 200mg alpha-folic acid, 5mg folic acid, $5 \mathrm{mg}$ biotin, $50 \mathrm{mg}$ benfotiamine and $5 \mathrm{mg}$ vitamin B6), there has been significant improvement of neuropathic symptoms. Negrão et al. ${ }^{11}$ have also shown improved neuropathic pain after 60 days of daily use of vitamin B12 (3 $\mu \mathrm{g})$ associated to uridine monophosphate $(50 \mathrm{mg})$ and folic acid $(400 \mathrm{mg})$, Talei et al. ${ }^{12}$, using this same vitamin but in a dose of muscular $2000 \mu \mathrm{g}$, twice a week for three months, have shown better efficacy of vitamin B12 as compared to nortriptyline $(10 \mathrm{mg})$ in diabetic polyneuropathy patients ${ }^{12}$. Stracke et al. ${ }^{13}$, using benfotiamine $(600$ or $300 \mathrm{mg}$, orally, once a day during six weeks) for diabetic neuropathy, have observed significant analgesic results, especially when higher doses were used. Other three studies, now addressing postherpetic neuralgias, have shown that local subcutaneous cobalamin $(1000 \mu \mathrm{g}$ once a day for 4 weeks) was superior to lidocaine to improve pain ${ }^{14-16}$.

So, it is suggested that the association of vitamins B12, B6 and $\mathrm{B} 1$, respectively and especially, in the doses of $1500 \mu \mathrm{g}$ (orally and daily) or $2000 \mu \mathrm{g}$ (muscular twice a week), of $50 \mathrm{mg}$ and of $300 \mathrm{mg}$ (both orally and daily), are effective as analgesic drugs for neuropathic pain.

As to publications about Bvits for nociceptive pain, 7 articles in total have also shown its analgesic effects. Chiu et al. ${ }^{17}$ have shown in chronic low back pain patients that vitamin B12 $(500 \mu \mathrm{g}$ muscular, three times a week for two months) has improved pain and associated functional incapacity. Also, Mibielli et al. ${ }^{7}$ have shown that vitamins B12, B6 and B1 $50 \mathrm{mg}$ pyridoxine, $50 \mathrm{mg}$ thiamine, $1 \mathrm{mg}$ cyanocobala$\mathrm{min}$ ) associated to anti-inflammatory drugs $(50 \mathrm{mg}$ diclofenac) have more effectively improved acute low back pain as compared to anti-inflammatory drug alone. And these same authors in a different study, now involving acute lumbar, cervical and hip pain ${ }^{18}$, have shown that nucleotides $(1.5 \mathrm{mg}$ uridine and $2.5 \mathrm{mg}$ cytidine) orally administered during 10 days, in association with vitamin B12 (1000 $\mu \mathrm{g})$ were effective in $51.23 \%$ of patients versus $87.5 \%$ when an antiinflammatory drug (diclofenac) was associated to the same nucleotides; however, associations with anti-inflammatory drugs are related to further risk of adverse effects. So, vitamin B12 as analgesic adjuvant could be an alternative for acute back, cervical and hip pain when there are higher risks for the use of anti-inflammatory drugs. In other nociceptive pains such as knee OA and pain after limb fracture, Bvits have also shown analgesic effects ${ }^{1,19,20}$, both alone and in association with anti-inflammatory drugs, in addition to benefits for inflammation (decreased C-reactive protein serum levels in monotherapy) and functional capacity ${ }^{19,20}$.

Although observing a role of Bvits as analgesics in nociceptive pain, it was not possible to establish most effective doses, as it also was the case for neuropathic pain, because formulations and doses of studied trials were quite different. However, it seems that muscular associations in single doses of thiamine $(100 \mathrm{mg})$, pyridoxine $(100 \mathrm{mg})$ and cyanocobalamin $(5000 \mu \mathrm{g})$, or just the weekly use of methylcobalamin $(1500 \mu \mathrm{g})$ are good options, as well as benfotiamine $(150 \mathrm{mg})$, pyridoxamine $(150 \mathrm{mg})$ and methylcobalamin $(1500 \mu \mathrm{g})$ formulations, orally during 180 days.

In light of the above, there is still the need for further studies and better standardization to try to establish most effective doses, best administration routes and Bvits administration time for nociceptive and neuropathic pain syndromes. To date, it is suggested that higher doses for longer periods lead to better results.

\section{CONCLUSION}

Our review has counted on recent, however very heterogeneous studies, pointing to analgesic effects of Bvits in different neuropathic or nociceptive pain syndromes, as adjuvant or as monotherapy. So, Bvits, that are considered safe and have low cost, could be good options for pain management in Brazil.

\section{REFERENCES}

1. Ponce-Monter HA, Ortiz MI, Garza-Hernández AF, Monroy-Maya R, Soto-Ríos, M, Carrillo-Alarcón L, et al. Effect of diclofenac with B vitamins on the treatment of acute pain originated by lower-limb fracture and surgery. Pain Res Treat. 2012;2012:104782.

2. Granados-Soto V, Sánchez-Ramírez G, la Torre MR, Caram-Salas NL, Medina-Santillán R, Reyes-García G. Effect of diclofenac on the antiallodynic activity of vitamin B12 in a neuropathic pain model in the rat. Proc West Pharmacol Soc. 2004;47:92-4.

3. Pérez-Flores E, Medina-Santillán R, Reyes-García G, Mateos-García E. Combination of diclofenac plus B vitamins in acute pain after tonsillectomy: a pilot study. Proc West Pharmacol Soc. 2003;46:88-90.

4. Rocha-González HI, Terán-Rosales F, Reyes-García G, Medina-Santillán R, Granados-Soto V. B vitamins increase the analgesic effect of diclofenac in the rat. Proc West Pharmacol Soc. 2004; 47:84-7.

5. Zhang M, Han W, Hu S, Xu H. Methylcobalamin: a potential vitamin of pain killer. Neural Plast. 2013;2013;424651.

6. Caram-Salas NL, Reyes-García G, Medina-Santillán R, Granados-Soto V. Thiamine and cyanocobalamin relieve neuropathic pain in rats: synergy with dexamethasone. Pharmacology. 2006;77(2):53-62.

7. Mibielli MA, Geller M, Cohen JC, Goldberg SG, Cohen MT, Nunes CP, et al. Diclo- 
fenac plus B vitamins versus diclofenac monotherapy in lumbago: the DOLOR study. Curr Med Res Opin. 2009;25(11):2589-99.

8. Jolivalt CG, Mizisin LM, Nelson A, Cunha JM, Ramos KM, Bonke D, et al. B vitamins alleviate indices of neuropathic pain in diabetic rats. Eur J Pharmacol. 2009;612(1-3):41-7.

9. Ang CD, Alviar MJ, Dans AL, Bautista-Velez GG, Villaruz-Sulit MV, Tan JJ, et al. Vitamin B for treating peripheral neuropathy. Cochrane Database Syst Rev. 2008;16(3):CD004573

10. Maladkar M, Tekchandani C, Dave U. Post-marketing surveillance of fixed dose combination of methylcobalamin, alpha lipoic acid, folic acid, biotin, benfotiamine\& vitamin b6-nutripathy for the management of peripheral neuropathy. J Diabetes Mellitus. 2014;4:124-32.

11. Negrão L, Almeida P, Alcino S, Duro H, Libório T, Melo Silva U, Figueira R, et al. Effect of the combination of uridine nucleotides, folic acid and vitamin B12 on the clinical expression of peripheral neuropathies. Pain Manag. 2014;4(3):191-6.

12. Talaei A, Siavash M, Majidi H, Chehrei A. Vitamin B12 may be more effective than nortriptyline in improving painful diabetic neuropathy. Int J Food SciNutr. 2009;60(Suppl 5):71-6.

13. Stracke H, Gaus W, Achenbach U, Federlin K, Bretzel RG. Benfotiamine in diabetic polyneuropathy (BENDIP): results of a randomised, double blind, placebo-controlled clinical study. Exp Clin Endocrinol Diabetes. 2008;116(10):600-5.

14. Xu G, Lv ZW, Feng Y, Tang WZ, Xu GX. A single-center randomized controlled trial of local methylcobalamin injection for subacute herpetic neuralgia. Pain Med. 2013;14(6):884-94.

15. Xu G, Xú G, Feng Y, Tang WZ, Lv ZW. Transcutaneous electrical nerve stimulation in combination with cobalamin injection for postherpetic neuralgia: a single-center randomized controlled trial. Am J Phys Med Rehabil. 2014;93(4):287-98.

16. Xu G, Lv ZW, Xu GX, Tang WZ. Thiamine, cobalamin, locally injected alone or combination for herpetic itching: a single-center randomized controlled trial. Clin J Pain. 2014;30(3):269-78

17. Chiu CK, Low TH, Tey YS, Singh VA, Shong HK. The efficacy and safety of intramuscular injections of methylcobalamin in patients with chronic nonspecific low back pain: a randomised controlled trial. Singapore Med J. 2011;52(12):868-73.

18. Mibielli MA, Nunes CP, Cohen JC, Scussel AB Jr, Higashi R, Bendavit GG, et al. Treatment of acute, non-traumatic pain using a combination of diclofenac-cholestyramine, uridine triphosphate, cytidine monophosphate, and hydroxycobalamin. Proc West Pharmacol Soc. 2010;53:5-12.

19. Garg S, Syngle A, Vohra K. Efficacy and tolerability of advanced glycation end-products inhibitor in osteoarthritis: a randomized, double-blind, placebo-controlled study. Clin J Pain. 2013;29(8):717-24.

20. Magaña-Villa MC, Rocha-González HI, Fernández del Valle-Laisequilla C, Granados-Soto V, Rodríguez-Silverio J, et al. B-vitamin mixture improves the analgesic effect of diclofenac in patients with osteoarthritis: a double blind study. Drug Res. 2013;63(6):289-92. 